\title{
Good Governance with Chinese characteristics: A perspective of China's Socialist Model
}

\author{
Hans Nibshan Seesaghur \\ PhD Candidate in Public Administration \\ School of Political Science and Public Administration, Wuhan University \\ China 430072 \\ E-mail: Hans230@yahoo.com, Telephone: +8613871180628 \\ Doi:10.5296/ jpag.v5i3.8028 URL: http://dx.doi.org/10.5296/ jpag.v5i3.8028
}

\begin{abstract}
Since the 1990s, scholars around the world have focused on the complexities of governance reforms. The vicissitudes of the 21st century witnessed global waves for public administration reforms. China, a fast developing socialist country, has been building a strong, robust and modern public governance system. The Socialist Governance of China with Chinese characteristics brought considerable changes in the political, economic and social spheres, transforming the lives of people for betterment. By bringing about economic development through state intervention, introducing rule of law upholding the significance of its people, fostering new ideas, and ushering the ideology of nationalism through "China Dream", President Xi Jinping and his socialist governance policies have created an excellent example in the world, particularly the capitalist society, demonstrating how society can be developed through socialist ways. Yet, the dynamics of Chinese governance has always been part science and part mystery to other governments that have earned legitimacy through elections, while China's leaders earned its legitimacy through selection of the most able and their performance in delivering sustained improvements in the quality of life of the Chinese citizens and China's international standing. This paper deals with assessing the relevance of China's Socialist governance evolution into a science of managing public affairs and the pursuit to optimizing its impact on the state's economic, political and social spheres.
\end{abstract}

Keywords: Socialist, China, Governance, policies 


\section{Introduction}

China's ideology of socialist governance is still in its primary stage, as reflected in the flexibility of its economic policies aimed to develop into an industrialized nation ${ }^{1}$, and its interpretation of the Marxist policy tailored to its needs and for the sustainability of the governance in the present world order. China follows the idea of scientific socialism, which emphasizes on the socialist market economy, dominated by the public sector and controlled by the government. The First Five-Year Plan clearly demonstrated the socialist policies similar to those of the former Soviet Union. Various initiatives, such as a central planning apparatus along with a set of central ministries and government institutions, reflect socialist governance.

Since the Chinese government's main goal is the creation and establishment of a socialist society and that China's governance is based on principles of proletariat (Silvio Pons \& Robert Service 2012), China portrays itself as a nation that believes in exercising the leadership of the working-class . Due to its understanding of the proletariats and the adoption of a socialist governance model to uplift the condition of the deprived class, most of the socialist government's investment in the First Five-Year Plan was directed towards the urban economy leading to the transition in the rural and urban economy of China to collective forms. Consequently, China has been able to garner both researchers' and leaders' attentions due to its deep understanding of its people's life, but also due to a poor understanding of its population politics (Greenhalgh \& Winckler 2005).

According to Swagel (2012), China is currently morphing into a country with political and social freedom, by gradually easing its hold on capital inflows, communications, internal migration, and paving the way for economic reforms. He also opined that the Chinese socialist leadership is coping with its economic challenges through the diversion of its growth and resources towards domestic demands along with policies like liberalization of trade and capital inflows (Swagel 2012). In late October 2014, the Chinese Communist Party (CCP) held its Fourth Plenum of the 18th Party Congress, to decide on major issues regarding party building, country governance (Laband \& Liu, 2014). A great emphasis was put on improving the administration of law ( $\mathrm{Ng} \&$ Zhang, 2014) by implementing the "socialist rule of law (Tiezzi, 2014). The socialist governance model under President Xi Jinping reflects a paradigm shift in the state's economic and political sector, thereby influencing its social sphere. Rather than renewing the Party's thinking, the current leader has formed a new nationalist rhetoric of "Chinese Dream" focused on wealth and power through state intervention contrasting with western ideas of economic liberalization. President Xi Jinping also upheld the urgency of rule of law, a core attribute of socialist form of governance, to enhance the position of its people as primary actors, but in line with the Chinese characteristics rather than capitalism's rule of law. In such a situation where easing of economic control is paving the way for long-term economic development, political freedom will also make its way, leading to the improvement of the society and enabling its citizens to enjoy personal freedom "ensuring the fact that the will of the people is embodied not just in

\footnotetext{
${ }^{1}$ The concept of China's position in the primary stage of socialism was first mentioned by Mao Zedong, as the Chairman of the CCP's Central Committee, at the First Zhenzhao Conference (2-10 November, 1958) (Li 1995).
} 
laws...but also in their enforcement" (Jinping 2015a). .

\section{Aim of the Study}

The paper aims to assess Good Governance with Chinese Characteristics in China's Socialist Governance Model and its impact on the political, economic and social spheres of the country.

\section{China's Socialist Governance model}

\subsection{Good Governance}

The concept of good governance embodies the idea of transforming the lives of people especially in the context of developing countries via models which follow the Rule of Law and where the public will be provided with transparent, fair, judicious, accountable, participatory, responsive, well- managed and efficient institutions. Thus, the concept establishes the idea of an ideal form of governance - the idea of 'how government ought to be carried out', as Merilee (2010) points out. Proponents of the concept view it not only as a major ingredient behind economic growth and development but also the driving force behind other types of political and social outcomes (Gisselquist 2012). Former United Nations Secretary General Kofi Annan also described good governance as 'perhaps the single most important factor for eradicating poverty and promoting development' (Annan 1998). The World Bank refers to good governance as the accountability, transparency and the efficiency with which the public institutions perform, rule of law and ordered interactions in politics (Anon 2007). United Nations Development Program (UNDP) promotes good governance, as it ensures the application of key features such as participation, transparency, accountability, effectiveness and equity, in the public sectors of a country. Thus good governance is about the processes for making and implementing decisions. It's not about making 'correct' decisions, but about the best possible process for making those decisions.

\subsection{Socialist Governance versus Democratic Governance}

Ever since the concept of Socialism was formed in the early 1830's, it has been described and explained by various thinkers, leading to a varied range of interpretations of the term, such that there is no particular definition of the term. It differs from "person to person, across time and national boundaries" (Lovell D.W 2002). The concept of socialism means the "collective ownership and democratic management of the means of production for common good" (Ghent W.J. 1916). The socialist form of governance, originating during the French Revolution, aims to bring in the society development of the common people through economic improvement and industrialization, by rejecting monopolistic practices and ensuring welfare, economic growth and greater efficiency.

On the other hand when defining the concept of Democracy, Robert Dahl (1989) considered some key indicators of electoral democracy, such as universal suffrage, elections registering voter preferences faithfully, and unbiased choice among alternatives, but did not mention if these indicators ensured good governance (Dahl, 1989). 
Unlike Western leaders, Chinese leaders are not elected following the ballot system but via a unique recommendation and selection of “the wise and able" (推贤举能). Hence, the obvious difference between Chinese governance and Western governance lies in a single letter of the alphabet: "S" - "selection" vs. "election" (Jin Kai. 2015). The Chinese socialist governance does not seem to trust a single election when trying to choose the national leaders, since that could be too risky for such a geographically huge and ethnically, economically, and culturally diverse country. Over the past two decades, various Chinese leaders have championed differing visions: Jiang Zemin (the $5^{\text {th }}$ President) urged cadres ${ }^{2}$ to "rule the country by virtue (以德治国)", Hu Jintao (the $6^{\text {th }}$ President) had "the campaign to maintain the advanced nature of Communist Party members (党员先进性教育)", and now Xi Jinping (the $7^{\text {th }}$ and current President) seeks “to establish the people with virtue (以德立人)." The previous generations of Chinese leaders were very enthusiastic about educating party cadres and the public with ethical and rhetorical practices for the betterment of the lives of China's citizens.

Over the years, the socialist governance model of China has shown considerably more legitimacy than most of the liberal democracies governance models such as the U.S.A. Since China, is a civilization-oriented state as opposed to the idea of nation-state of the West, China emphasizes on the civilization's integrity and unity, thus legitimizing its relationships with the Chinese civilization (Jacques 2012). Furthermore, socialism has improved the economic performance of China over the past three decades, eradicating $70 \%$ of world's poverty and increasing its GDP multi-fold, leading to an 18-fold growth in its economy since 1979 (Weiwei 2013). China's astounding economic success seems to demonstrate that good governance is associated with effectiveness, efficiency and responsiveness in the public institutions which are maintained by the socialist model with Chinese characteristics, without going through elections. This contrasts starkly with democratic governance coined as being the most 'people-oriented' form of government. Until now, China's leadership has been successful in ensuring good governance to its citizens through pragmatic reforms, and developing the country both internally and externally by strengthening its ties with other countries. China stands out as an emergent super power, and exerts a strong presence in the global sphere.). China has managed to create an example of successful governance by infusing socialist ideology with Chinese characteristics.

Last but not least, it should be noted that there is a clear distinction between the western idea of "rule of law" and the socialist idea, which at best could be regarded as "rule by law" (Shi, 2014).

\subsection{History of Socialist Governance in China}

In the backdrop of a bipolar world order post-WWII, China chose to follow the Soviet strategy of socialism, thus establishing state-controlled machinery. It managed to eliminate the gentry-landlords, bureaucratic landlords and foreign capital outflows, and kept the surplus

\footnotetext{
${ }^{2}$ In 1987 the party and government cadre ( $\mathrm{ganbu}$ ) system, the rough equivalent of the civil service system in many other countries, was entering the final stages of a massive overhaul aimed at transforming the bureaucracy into an effective instrument of national policy. The term cadre refers to a public official holding a responsible or managerial position, usually full time, in party and government. A cadre may or may not be a member of the CCP, although a person in a sensitive position would almost certainly be a party member.
} 
in its own hands to establish a centralized state ownership of production and monopoly in the domestic market. China's gross domestic product (GDP) in the early $19^{\text {th }}$ century was nearly one third of the world's GDP, making it one of the largest territorial economies in the world ( $\mathrm{Li}$ 2008; Locatelli 2010). However, successive defeats and territory cession made the country one of the poorest by the $20^{\text {th }}$ century. The Chinese Liberation movement saw the emergence of national bourgeoisie as the leader but their numerical and financial deficiency led them to establish connection with the gentry-landlord and paved the way for the rise of financial bourgeoisie who in turn were dependent on the foreign players for finance, technology and market. Thus, all these changes in the society led to the accumulation of wealth in fewer hands, detaching the masses ( $\mathrm{Li} 2008)$.

By the 1930s, after the collapse of Qing dynasty and the failure of Sun Yat-sen's Nationalist Party in establishing a democratic government, China degenerated into a 'corrupt, military bureaucratic clique' ( $\mathrm{Li}$ 2008). The implementation of socialist form of governance posed as a challenge because the country was already submerged in grave economic crisis due to the WWII and civil wars and recovering from such a situation amidst a capitalist world order was difficult. Eventually, the introduction of the socialist form of governance with Chinese characteristics transformed the political, social and economic scenarios in the country and its international relationships ( Li 2008; Locatelli 2010).

The Chinese socialist governance model pointed towards the elimination of the enemies of the state (i.e. the bourgeoisie, bureaucratic capitalists, etc.) and aimed at the upliftment of the peasantry and the working class who until then belonged to the marginalized section. Economic development in Mao's China (c. 1949-79) was directed towards the eradication of hunger and malnutrition - the two basic yardsticks that needs prioritization in a developing society. As Navarro declared, socialism addresses these key issues better than capitalism (Navarro 1993). Post Mao's era (1979-2009), the government adopted a capitalist policy to integrate itself within the world market. After coming to power in 1979, Deng Xiaoping introduced capitalism-like reforms for the economic development of the country via industrialization and modernization (a crucial feature of socialism). This brought development to the country through measures like family contract system- privatizing agriculture, which benefited both peasants and urban households(Deng 2009). After China's adaptation of some of the capitalist policies and decentralization, considerable economic growth and development was noticed, with continuing improvement in the market system, more overseas trade, foreign investment and international co-operation, thereby propelling China as a super power in the politico-economic world order.

\section{Impact of China's Socialist Governance Model on its economic, political and social spheres}

China's socialist form of government underwent a change 35 years ago after the formation of the Chinese socialist government and its internal economic and political relations with other socialist countries of Soviet Union and Cuba. Like the other socialist countries, China faced immense pressure from both military and economic prime capitalist powers. This compelled it to extract surplus from the working class and accumulate a larger share in the government's 
hands so as to invest in the economical, political and social spheres.

As President Xi Jinping (2015) opined in his book The Governance of China (2014), being in the primary stage of socialism, China is running backwards in social production, thereby placing the socialist governance in a contradictory position, between the effectively administration of the state according to the socialist principles and the rise of material and cultural needs of the masses (Jinping 2015b). After the 2008 economic crisis, the concept of China model gained momentum, which saw the Chines elites' turn their back against the Western political and economic systems and embrace a new way of Chinese development. The China model was meant to make the idea of socialism successful by deviating from the theoretical perspectives of Marx and Engels and discarding the mistakes committed by the Soviet Union, which lead to its collapse.

\subsection{Economic Impact}

After the opening up of the Chinese markets to foreign players and welcoming of foreign capital, China's economy witnessed a considerable growth of nearly $10 \%$ every year, positioning it as the second fastest growing county in the world (Yiwei 2014). While most of the European countries are struggling to regain its economic condition after the international economic crisis, China's economy revived contrastingly. As explained by Yiwei (2014), this was due to "The Five Integrations" policy adopted by China's socialist government. Under this policy,

1. market was given a major and decisive role in the allocation of resources, primarily with public ownership, "supported by other ownership economies as well"(Yiwei 2014).

2. Integrating markets' efficiency in resource allocation, effectively and timely, with maintenance of fairness during the whole process and at the end of such allocation, contributed greatly to the economic revival.

3. The socialist governance integrated its opening up (of its market and products) and reform to comply with the international system.

4. It integrated rapid development with sustainable development.

5. Lastly, the integration of goals "short-term goals and long-term goals and partial and complete goals" and methods, resulted in the stabilization of the nation.

All these initiatives have been further boosted by the "One Belt One Road" policy adopted by the contemporary President Xi Jinping for achieving a number of goals like "increased diplomatic coordination, standardized and linked trade facilities, free trade zones, people- topeople cultural education programs" and integrating the Eurasian region, financially (through Asian Infrastructure Investment Bank), diplomatically and culturally (Stokes 2015). This policy further enhances the China Dream by increasing the annual trade with the BRICS ${ }^{3}$ nations up to $\$ 2.5$ trillion within a decade and hence as emphasized by Stokes (2015),

\footnotetext{
${ }^{3}$ BRICS is the acronym for an association of five major emerging national economies: Brazil, Russia, India, China and South Africa.
} 
boosting the Chinese economy through "excess industrial capacity "and boosting employment.

\subsection{Political Impact}

Politically, China's socialist governance model had a huge impact in bringing high efficiency by assigning democratic form in the government department and institutions and maintaining a centralized power to control the nation. It has also adopted a duty division and collective responsibility approach, along with establishing grass-roots level of democracy by delegating power to the departments. Moreover, the governance has adopted some bold attempts by breaking away from conventional socialism (Yiwei 2014). Under the leadership of President $\mathrm{Xi}$ Jinping, China underwent a transformation, a renaissance by smoothing its ties with other countries, especially with its neighbors. Through One Belt One Road, the socialist governance has been able to and is still working towards consolidating the powers of the Eurasian countries, further developing its socialist ideology and strengthening its presence in the international sphere. The Chinese socialist governance leadership has been trying to overcome the somewhat illusory nature of ethics in politics described by many Western democratic governance leaders. China summarizes its policies toward neighboring countries with four Chinese characters: “亲, 诚, 惠, 容,” meaning “amity, sincerity, mutual benefit, and inclusiveness." Meanwhile, China acknowledges but does not overemphasize the importance of hard power when it comes to conflicts and disputes, and especially strives to avoid the "natural" and "inevitable" conflicts between states that classical realists associate with great power relations.

\subsection{Social Impact}

Socially, the socialist governance has contributed in making China a civilized and developed nation by opening up to the world system, integrating the excellent civilization systems, and shifting from the traditional to the new via the incorporation of innovative ideas but withholding the old civilization. With the policies of One Belt One Road, the new Asian Infrastructure Investment Bank and trade and market liberalization, the socialist governance model is able to boost employment, hence upgrading the living standard of the people. Cultural integration among Eurasian countries and leniency in the regulation to travel abroad (such as the provision of visas to foreign countries) has boosted the education sector by. Chinese students have the opportunity to pursue their studies abroad, and enrich their experience by interacting with foreign students, scholars and researchers, thereby transcending "both China-centered ideology or West-centered ideology" (Yiwei 2014).

\section{Conclusion}

The Socialist Government of China underwent several changes since its implementation in 1949. According to President Xi Jinping (2015), the Chinese government has developed a new idea of socialism with the Chinese characteristics upholding the socialist rule of law and good governance. Through its various policies China's Socialist Governance Model has greatly impacted on the life of its people, it has considerably improved China's economic, political and social conditions though the integration of open markets, democratization of its 
departments and centralization of power in the country. China's Socialist Governance Model is continuously adapting itself to strengthen its hold in a capitalist world order, by incorporating various approaches, deviating from core socialist ideas, learning from the mistakes committed by the erstwhile Soviet Union, maintaining law-based governance, keeping people in the priority and upholding the principle of equality before the law (Jinping 2015a). In the view of the world current situations, China's Socialist Governance model phenomenon reflects good governance and is an important part not only for China's own development but also exerts increasingly profound influences on the regional and global governance. (Yi Wei 2014).

\section{Acknowledgement}

The research was conducted under the Chinese Government Scholarship - Bilateral Program.

\section{References}

Anon, 2007. Strengthening World Bank Group Engagement on Governance and Anti-Corruption.,

China, after the N. xi J.R. for, 2014. After the NPC: Xi Jinping's Roadmap for China, Washington DC. Available at: http://www.brookings.edu/research/opinions/2014/03/11-after-npc-xi-jinping-roadmap-for-ch ina-kroeber [Accessed May 1, 2015].

Ghent, W.J., 1916. The Elements of Socialism. In W. J. Ghent, ed. The New Appeal Socialist Classics. Kansas: The New Appeal, pp. 1-46. Available at: http://debs.indstate.edu/e389e4_1916.pdf [Accessed May 12, 2015].

Gisselquist, R., 2012. Good Governance as a Concept, and Why This Matters for Development Policy, Helsinki.

Greenhalgh, S. \& Winckler, E.A., 2005. Governing China's Population: From Leninist to Neoliberal Biopolitics, California: Stanford University Press.

Good Governance Guide. Available at: http://www.goodgovernance.org.au/about-good-governance/what-is-good-governance/\#sthas h.4m6nPslQ.dpuf [Accessed June 09, 2015].

Jacques, M., 2012. A Point Of View: Is China more legitimate than the West? - BBC News. BBC Magazine. Available at: http://www.bbc.com/news/magazine-20178655 [Accessed May 12, 2015].

Jin Kai., 2015. Are China's Leaders Disciples of Machiavelli? - The Diplomat.China Power. Available at :

http://thediplomat.com/2015/02/are-chinas-leaders-disciples-of-machiavelli/ [Accessed June $02,2015]$.

Jinping, X., 2015a. Accelerating the Establishment of Socialist Rule of Law in China _ Qiushi Journal. English Edition of Qiushi Journal, 7(22). Available at: 
http://english.qstheory.cn/2015-03/16/c_1114459319.htm [Accessed May 13, 2015].

Jinping, X., 2015b. Xi Jinping: The Governance of China. illistrate., Shanghai Press.

Kent G. Deng, 2009. Economic Growth of the People's Republic of China, 1949-2009. Macquarie University.

Kofi Annan, 1998. Annual Report of the Secretary General on the Work of the Oranization,

Li, G., 1995. A Glossary of Political Terms of the People's Republic of China, Hongkong: Chinese University Press.

Lovell, D.W, 2002. Socialism and Communism. Government and Politics, II, pp.1-21. Available at: http://www.eolss.net/sample-chapters/c04/e6-32-04-05.pdf [Accessed May 12, 2015].

Minqi Li, 2008. Socialism, Capitalism, and Class Struggle: The Political Economy of Modern China. Economic and Political Weekly, pp.77-85. Available at: http://cis.uchicago.edu/outreach/summerinstitute/2009/documents/cis_sti2009-mehta-political _economy_of_modern_china.pdf [Accessed April 30, 2015].

Niccolo Locatelli, 2010. China in Latin America: Political and Economic Implications of Beijing's Involvement in the Region, Universal Publishers.

Robert Dahl, 1996. Democracy And Its Critics, New Haven, CT: Yale University Press.

Silvio Pons \& Robert Service, 2012. Communist Party in China. In A Dictionary of 20th-Century Communism. Princeton, New Jersey: Princeton University Press, pp. 155-160. Available at: http://press.princeton.edu/chapters/pons/s1_9143.pdf [Accessed April 29, 2015].

Stokes, J., 2015. China's Road Rules | Foreign Affairs. Foreign Affairs. Available at: https://www.foreignaffairs.com/articles/asia/2015-04-19/chinas-road-rules [Accessed May 21, 2015].

Swagel, P., 2012. China's transition: Three scenarios. American Enterprise Institute, p.1. Available at: http://www.aei.org/publication/chinas-transition-three-scenarios/ [Accessed April 30, 2015].

Vicente Navarro, 1993. Has Socialism Failed? An Analysis Of Health Indicators Of Capitalism and Socialism. Science \& Society, 57(1), pp.6-30.

Wang Gungwu \& Yongnian Zheng, 2012. China: Development and Governance. W. Gungwu $\&$ Y. Zheng, eds., Singapore: World Scientific.

Weiwei, Z., 2013. Why China prefers its own political model | Europe's World. Europe's World, Spring. Available at: http://europesworld.org/2013/02/01/why-china-prefers-its-own-political-model/\#.VVGnCY6 qpHx [Accessed May 12, 2015].

Yiwei, W., 2014. China Model Not Only Develops China but Also Benefits the World. People's

Daily.

Available

at: 
http://en.theorychina.org/xsqy_2477/201412/t20141216_315983.shtml [Accessed May 13, 2015]. 